\title{
O bułgarskiej polityce językowej w kontekście postępującej integracji europejskiej i w obliczu globalizacji
}

\author{
Българска езикова политика в условията на европейска \\ интеграция и глобализация, \\ red. Диана Иванова, Университетско издателство \\ „Паисий Хилендарски”, Пловдив 2012, ss. 233
}

\begin{abstract}
Wydany w Płowdiwie tom zbiorowy pod redakcją Diany Iwanowej stanowi jedynie część zakrojonego na szeroką skalę projektu zatytułowanego Българската националноезикова политика и кониепиии за езиково и литературно наследство в условията на европейска интеграция и глобализаиия (Bułgarska narodowa polityka językowa oraz koncepcje dziedzictwa językowego i literackiego w warunkach integracji europejskiej i globalizacji). W jego ramach przewidziano m.in. dyskusję nad wyjątkowo aktualnym i ważkim problemem rozwoju bułgarskiej polityki językowej, w tym zwłaszcza jej kierunkami w kontekście zachodzącego obecnie procesu integracji europejskiej. Szczególną uwagę skierowano na kulturowy aspekt różnorodności językowej w Europie, lecz zagadnienie polityki językowej zostało rozpatrzone w kilku kontekstach: instytucjonalnym, edukacyjnym, prawodawczym, ponadnarodowym, translacyjnym, a także pragmatyki językowej.

Książka Българска езикова политика в условията на европейска интеграция и глобализация (Bułgarska polityka językowa w warunkach europejskiej integracji i globalizacji) jest owocem współpracy naukowców reprezentujących siedem ośrodków naukowych w czterech krajach europejskich (Bułgaria, Czechy, Polska, Szwecja). Przyjęto w niej podział tekstów na trzy działy z uwzględnieniem perspektywy historycznej i współczesnej. W pierwszej części Корени на българската езикова политика - ресурси на историческото минало zostały poddane analizie warunki
\end{abstract}


kształtowania się i rozwoju języka bułgarskiego, przy czym w większości ujęć wyraźnie zarysowuje się obraz języka narodowego jako istotnego elementu w konstruowaniu tożsamości narodowej i dziedzictwa kulturowego Bułgarów. Referaty ukazują specyfikę bułgarskiego odrodzenia narodowego i miejsce języka w polityce ukierunkowanej na kształtowanie tzw. świadomej tożsamości narodowej Bułgarów oraz odzyskania podmiotowości prawnej przez państwo bułgarskie. Pierwszy z artykułów (Д. Вeселинов Езици и етноси в „История славаноболгарская” на Паисий Хилендарски) odkrywa nową perspektywę odczytania przesłanek, jakie niesie ze sobą Historia stowianobutgarska Paisija Chilendarskiego. Jego autor stawia tezę, zgodnie z którą dzieło to stanowi „национален манифест за развитие на българското образование, кодифициран със сакралността на ръкописната традиция" (kodyfikowany sakralną tradycją piśmienniczą manifest narodowy o rozwoju szkolnictwa bułgarskiego). Odrodzeniowa koncepcja języka jako nośnika istotnych treści tożsamościowych, postulat jego kodyfikacji są obecne w artykułach Tanii Buczkowеј Визия за езиковото наследство и езиковото бъдеще в „Ццариградски вестник" (1848-1862), Marii Mickowej Възрожденската езикова политика (въпроси на правоговора в предговорите на книги в периода 20-те - 70-те години на ХІХ в.), Pontusa Lindgrena Изповедите не един „Ероеретік” (за идейно-философските корени на езиковата програма на Иван Добровски в сn. „Мірозреніе” (1850-1851) i Eleny Getowej Ресурси от историческото минало на книгата. 3 а оригинала и преводите на една популярна повест през българското възраждане. Oparte na niezwykle skrupulatnej analizie teksty dostarczają wielu szczegółowych danych na temat uprawianej na łamach prasy odrodzeniowej oraz postulowanej przez wybranych działaczy tego okresu polityki językowej. W tej części tomu na specjalną uwagę zasługuje artykuł Borisława Borisowa Езикът и властта (ресурси от миналото и настоящето на езика), w którym z powodzeniem została podjęta próba przeglądu relacji między językiem (jako wyznacznikiem wspólnotowości narodowej) a władzą w kontekście funkcjonowania państwa bułgarskiego w różnych momentach historycznych, w tym także w sytuacji braku podmiotowości prawnej. Z kolei tekst Nadki Nikołowej Съвременната българска езикова ситуация с оглед на темата за езиковата чистоma podnosi problem puryzmu językowego i jego przejawów wśród postaw 
językoznawców i użytkowników języka bułgarskiego na różnych etapach jego rozwoju. Autorka, mając na uwadze zjawisko globalizacji, uznaje obecne stadium bułgarszczyzny za moment ekstremalny funkcjonowania etnosu. Wychodząc z założenia, że zjawisko puryzmu językowego przybiera szczególnie wyrazistą formę w sytuacji poczucia zagrożenia, płynącego z uwarunkowań zewnątrzjęzykowych, przygląda się postawie autorytetów językoznawczych, ale także użytkowników języka (bada blogi i fora internetowe). Konstatuje, że zarówno wśród jego nosicieli, jak i specjalistów przeważa pragmatyczno-racjonalny stosunek do obcej leksyki. Psycholingwistyczny aspekt badawczy, choć niezwykle interesujący, byłby niewątpliwie bardziej przekonujący, gdyby został poparty większą liczbą konkretnych danych ( $\mathrm{z}$ tekstu bowiem nie wynika, które strony WWW stanowiły podstawę analizy).

Tytuł drugiej części Езикови политики в контекста на европейска интеграция wskazuje na wielotorowość podejmowanych w ramach społeczności wspólnotowej działań poszczególnych państw w zakresie polityki językowej. Najwięcej na ten temat dowiadujemy się z artykułu Mimi Kornażewej (Европейски езикови политики и сигурност), która uwypukla ogromny potencjał drzemiący we wspólnototwórczej sile języka. Autorka, starając się dokonać obiektywnego oglądu rzeczywistości językowej w wybranych państwach europejskich, prezentuje postanowienia wiążących aktów prawnych, dotyczących zwłaszcza statusu i ochrony języka narodowego, w tym także polityki wobec mniejszości narodowych i etnicznych oraz ludności imigracyjnej. Tok przeprowadzonej tu analizy pokazuje wyraźnie, że w kontekście realizowanych polityk językowych państw europejskich nie może być mowy o ,globalizmie kulturowym”. Badaczka zwraca uwagę na kluczową kwestię, jaką jest postrzeganie języka narodowego w perspektywie problemów tożsamościowych.

Ważne miejsce w tomie zajmuje artykuł Diany Iwanowej Българската езикова политика в контекста на езиковата политика на Европейския съюз - проблеми и перспективи. Autorka, wychodząc od przedstawienia szerokiej płaszczyzny wspólnotowej (którą stanowią decydujące o kształcie polityki językowej w krajach Unii Europejskiej akty prawne), przechodzi do analizy funkcjonowania konkretnych rozwiązań na gruncie bułgarskim. Sytuację językową w Bułgarii rozpatruje wielopoziomowo. Szczególną wartość mają jasno sformułowane wnioski, zwłaszcza 
zaś te demaskujące: 1) brak jakichkolwiek działań ze strony państwa, które uwzględniałyby dynamicznie zmieniający się skład ludnościowy społeczeństwa; 2) instrumentalne traktowanie kwestii języka narodowego w dyskursie politycznym. Z całą pewnością aktualnym problemem nie tylko w kontekście bułgarskiej rzeczywistości językowej, ale i w odniesieniu do wielu tzw. „małych języków narodowych” jest zjawisko ,językowego liberalizmu" polegające na propagowaniu swego rodzaju substandardu w języku mediów. Autorka uświadamia nam jednak, że w specyficznej sytuacji komunikacyjnej, w jakiej się znajdujemy (wynikająca z funkcjonowania w ramach struktur europejskich dominacja języka angielskiego w komunikacji międzynarodowej, tendencje globalizacyjne, nacisk na pragmatyczny aspekt komunikacji w nauczaniu języka), największe zagrożenie dla języka niesie obojętna postawa jego użytkowników, brak krytycznej świadomości i wygodnictwo umysłowe. W tym aspekcie interesujący okazuje się zrekonstruowany przez Petię Kostadinową (Наблюдения върху езиковите нагласи на съвременния българин) obraz języka bułgarskiego oparty na danych eksperymentalnych, uzyskanych na podstawie analizy ponad stu prac konkursowych na temat Język, wrażliwość i moralność. Co ciekawe, uczestnicy konkursu ocenili współczesną bułgarską praktykę językową jednoznacznie negatywnie, przy czym $75 \%$ spośród nich uważa, że odpowiedzialność za zachowania językowe spoczywa na każdym $\mathrm{z}$ nas z osobna.

Podjęte przez D. Iwanową wątki, dotyczące polityki językowej państwa względem obywateli bułgarskich za granicą oraz funkcjonujących poza krajem bułgarystyk, rozwijają i uzupełniają Cenka Iwanowa ( $3 a$ българския език в чужбина и за ролята на българската държава (между традициите и съвременните реалности)) i Elena Krejčova (Българските институции и университетското образование по български език в Чехия). W tym zakresie podzielają one pogląd o potrzebie stworzenia spójnej i skutecznej strategii działania ze strony państwa.

Poza wspomnianymi tekstami, w trzeciej części tomu znajdują się prace omawiające w sposób szczegółowy wybrane zagadnienia z zakresu zarówno pragmatyki językowej (Ю. Чакърова Преводът и локализацията в контекста на езиковата политика, Н. Михайлова-Сталянова Тенденции в съвременния политически език в България и тяхната кодификаиия), jak i glottodydaktyki (В. Маровска „Светът в езика”: 
дидактично-практическата и теоретическата граматика и принципите на чуждоезиковото обучение). Z kolei dzięki artykułom Marioli Walczak-Mikołajczakowej (Polska polityka językowa $i$ akty prawne dotyczqce języka) oraz Pawła Krejči (Конституцчия и език (црихи към езиковата политика на Сърбия и другите постсърбохърватски републики)) zyskujemy aktualny obraz polityki językowej uprawianej w Polsce i w krajach byłej Jugosławii.

Ostatnie dziesięciolecia upływały pod znakiem ciągle rosnącego zainteresowania badaczy przedmiotowym zagadnieniem. W prezentowanej pracy jest ono traktowane wielopłaszczyznowo, w ujęciu zarówno historycznym, jak i w kontekście dynamicznie rozwijającej się, aktualnej sytuacji językowej. Nie da się nie zauważyć takiej zalety tomu, jak choćby ukazanie zależności między polityką językową a problemami tożsamości narodowej czy europejskości. Zatem bibliografia slawistyczna została wzbogacona o cenną pozycję wydawniczą, która osadzając język z kręgu „małych języków narodowych” w szerokim kontekście europejskim, otwiera pytania aktualne dla wszystkich systemów słowiańskich.

Natalia Dtugosz 